\section{Propagation of Five Species in a Commercial- scale Submist System}

\author{
Stephanie E. Burnett ${ }^{1}$, Bryan J. Peterson ${ }^{1}$, and Marjorie Peronto ${ }^{2}$
}

AdDitional INDEX wORDs. blue star flower, cuttings, faassen nepeta, panicle hydrangea, sweetfern, sweetgale, water use

SUMMARY. The novel propagation system submist, which applies water to the bases of cuttings rather than overhead, is a promising alternative. We developed and tested a commercial-scale submist system to make this propagation system more accessible to commercial propagators. Five species, including blue star flower (Amsonia tabernaemontana), faassen nepeta (Nepeta $\times$ faassenii 'Six Hills Giant'), panicle hydrangea (Hydrangea paniculata 'Grandiflora'), sweetgale (Myrica gale), and sweetfern (Comptonia peregrina), were propagated from cuttings in commercial-scale submist and overhead mist systems. Blue star flower and faassen nepeta cuttings had greater root length, root rating, and root number with the submist system. Panicle hydrangea cuttings had more roots in submist, but longer roots in overhead mist. There were no differences in rooting between the systems for sweetgale and sweetfern cuttings. The comparable or superior rooting of these five species in a submist system compared with traditional overhead mist systems is evidence that submist is a viable alternative propagation system. Water use in submist systems was $\mathbf{9 8 \%}$ less than that for overhead mist systems.

S tem cuttings are traditionally propagated using overhead mist systems. Recent work has explored the use of a different approach: submist propagation (Peterson et al., 2018a, 2018b; Sanchez et al., 2020). Submist propagation systems apply water to the basal portions of cutting stems, rather than overhead. Cuttings are suspended in an enclosure that

Received for publication 4 Nov. 2020. Accepted for publication $11 \mathrm{Feb} .2021$

Published online 2 April 2021

${ }^{1}$ School of Food and Agriculture, 5722 Deering Hall, University of Maine, Orono, ME 04469

${ }^{2}$ University of Maine Cooperative Extension, 5741 Libby Hall, University of Maine, Orono, ME 04469

Funding for this research was provided by a Horticultural Research Institute grant and by the U.S. Department of Agriculture (USDA) National Institute of Food and Agriculture (NIFA) Hatch projects (\#ME01423) and Multistate Project (\#ME031901) through the Maine Agricultural \& Forest Experiment Station.

We thank Van Berkum and Pierson nurseries and Charlene Grey for providing plant materials. We greatly appreciate Andrew Chase, Lia MacLellan, and Bradly Libby for providing technical assistance.

Any opinions, findings, conclusions, or recommendations expressed in this publication are those of the authors and do not necessarily reflect the view of NIFA or USDA.

Maine Agriculture and Forestry Experiment Station Publication \#3795

S.E.B. is the corresponding author. E-mail: sburnett@ maine.edu.

This is an open access article distributed under the CC BY-NC-ND license (https://creativecommons.org/ licenses/by-nc-nd/4.0/).

https://doi.org/10.21273/HORTTECH04758-20 contains a manifold of mist nozzles. Plants propagated in this system may have superior rooting compared with those propagated in overhead mist (Peterson et al., 2018a, 2018b; Sanchez et al., 2020). After propagation, cuttings are transplanted into soilless media, and their growth is similar to that of plants propagated in overhead mist (Peterson et al., 2018a, 2018b).

Submist propagation systems were introduced in 1964 at the International Plant Propagators' Society Western Region annual meeting (Nitsch, 1964). They have been used experimentally to propagate semihardwood cuttings of peach [Prunus persica (Coston et al., 1983)]. Submist propagation systems are a relatively new concept in commercial operations. Previous research with these systems has been conducted on small-scale, custom-built submist units that are unsuited to commercial propagation because they hold few cuttings (Peterson et al., 2018a, 2018b; Sanchez et al., 2020 ). For the industry to adopt submist propagation, larger systems must be designed that can effectively hold the greater number of cuttings propagated at commercial greenhouses or nurseries.

One potential benefit of submist systems for propagation, compared with overhead mist, is that submist systems potentially use less water. This is because the enclosed system recycles water and reduces water losses to evaporation. Although we are unaware of research quantifying the amount of water used during overhead mist propagation, a survey of greenhouse growers indicated that 4.5 to $46.1 \mathrm{~L} \cdot \mathrm{m}^{-2}$ of leachate is produced over 4 weeks (Santos et al., 2008) Peterson et al. (2018b) found that submist systems used about the same amount of water for the entire time needed to propagate coleus (Plectranthus scutellarioides) as an overhead mist nozzle used in $30 \mathrm{~s}$. Techniques for reducing water use during propagation without impacting rooting negatively would help growers reduce their overall water usage.

Another potential benefit of using submist for propagation is that it may improve root development on some woody and herbaceous perennials that are challenging to propagate or that form roots slowly. In previous research, manchurian lilac (Syringa pubescens ssp. patula 'Miss Kim') had more roots and longer roots when it was propagated in submist (Sanchez et al., 2020). Manchurian lilac plants are often challenging to propagate if cuttings are not taken at the right time (Hartmann et al., 2002). A broader variety of species, including difficult-to-root plants, should be tested in submist propagation systems to determine whether

\begin{tabular}{clll}
\hline $\begin{array}{l}\text { Units } \\
\text { To convert U.S. to SI, } \\
\text { multiply by }\end{array}$ & U.S. unit & SI unit & $\begin{array}{l}\text { To convert SI to U.S., } \\
\text { multiply by }\end{array}$ \\
\hline 0.3048 & $\mathrm{ft}$ & $\mathrm{m}$ & 3.2808 \\
0.0929 & $\mathrm{ft}^{2}$ & $\mathrm{~m}^{2}$ & 10.7639 \\
3.7854 & $\mathrm{gal}$ & $\mathrm{L}$ & 0.2642 \\
40.7458 & $\mathrm{gal} / \mathrm{ft}^{2}$ & $\mathrm{~L} \cdot \mathrm{m}^{-1}$ & 0.0245 \\
0.7457 & horsepower & $\mathrm{kJ} \cdot \mathrm{s}^{-1}$ & 1.3410 \\
2.54 & inch $(\mathrm{es})$ & $\mathrm{cm}$ & 0.3937 \\
0.0254 & $\mathrm{mil}(\mathrm{s})$ & $\mathrm{mm}$ & 39.3701 \\
28,350 & $\mathrm{OZ}$ & $\mathrm{mg}$ & $3.5274 \times 10^{-5}$ \\
1 & $\mathrm{ppm}$ & $\mathrm{mg} \cdot \mathrm{L}^{-1}$ & 1 \\
$\left({ }^{\circ} \mathrm{F}-32\right) \div 1.8$ & ${ }^{\circ} \mathrm{F}$ & ${ }^{\circ} \mathrm{C}$ & $\left({ }^{\circ} \mathrm{C} \times 1.8\right)+32$ \\
& & & \\
\hline
\end{tabular}


these challenging species form roots more reliably or quickly in submist. For example, sweetfern (Comptonia peregrina) is challenging to propagate from stem cuttings. Although some growers propagate sweetfern from rhizomes, the technique is slow and it limits the number of plants available (Griffith Gardner et al., 2019). Blue star flower (Amsonia tabernaemontana) is propagated from seed or by stem cuttings, which often form roots slowly (Hartmann et al., 2002).

Our three objectives for this study were 1) to determine whether submist propagation systems could be modified for commercial-scale propagation, 2) to compare water usage between submist and traditional overhead mist propagation systems, and 3 ) to compare rooting of several shrubs and herbaceous perennials propagated in both submist and overhead mist systems. Two of five species in this study (sweetfern and blue star flower) are difficult to propagate using stem cuttings. The other three species, faassen nepeta (Nepeta $\times$ faassenii 'Six Hills Giant'), sweetgale (Myrica gale), and panicle hydrangea (Hydrangea paniculata 'Grandiflora') are easy to propagate.

\section{Materials and methods}

Cuttings from five species of plants were propagated in commercial-scale submist and overhead mist systems. On 20 June 2019, tip cuttings were taken from containergrown plants of blue star flower and faassen nepeta at a commercial nursery in New Hampshire. Cuttings were collected in a plastic cooler for transport to campus, stored in a floral cooler overnight, and inserted into substrate for rooting the following day. Cuttings of blue star flower had 10 nodes and were 6 inches long. Cuttings of faassen nepeta had three nodes and were 4 inches long. Faassen nepeta were flowering prolifically when we took cuttings; we did not remove the flowers. Cuttings of both species were dipped in $1000 \mathrm{mg} \cdot \mathrm{L}^{-1}$ potassium salt of indole-3-butyric acid (KIBA) for $5 \mathrm{~s}$ and then briefly air-dried before insertion into either propagation system. Herbaceous perennial cuttings in the submist systems were briefly hand misted for $10 \mathrm{~s}$ once each hour on the day cuttings were inserted into substrate for rooting (10:00 AM-6:30 PM), after which they received no overhead mist for the remainder of the experiment. Softwood tip cuttings of panicle hydrangea and sweetgale were taken on 21 June 2019 at a commercial nursery in Maine, stored in a floral cooler, and inserted into substrate for rooting the following day. Panicle hydrangea cuttings had three to four nodes, were 4.3 inches long, and were dipped for $5 \mathrm{~s}$ in $1000 \mathrm{mg} \cdot \mathrm{L}^{-1} \mathrm{KIBA}$. Sweetgale cuttings had 10 to 12 nodes, were 4 inches long, and were not treated with exogenous hormone (Peterson et al., 2019). Softwood tip cuttings of sweetfern were obtained from a private residence in Blue Hill, ME, on 26 June 2019 and were inserted into propagation systems the same day. Tip cuttings ( $\approx 4-5$ inches long) were taken from new shoots emerging directly from the ground next to established plants, presumably from underground rhizomes. These softwood cuttings were dipped for $5 \mathrm{~s}$ in $8000 \mathrm{mg} \cdot \mathrm{L}^{-1} \mathrm{KIBA}$, and air-dried briefly before they were inserted into the two systems. For all species, crosscontamination of KIBA between species was unlikely to be a problem because the volume of water in the submist reservoir will dilute any KIBA rinsed-off cuttings to less than $1 \mathrm{ppm}$ in the recirculating water.

In overhead mist, cuttings were propagated in premoistened substrates of supercoarse horticultural perlite (Whittemore Co., Lawrence, MA) and milled peatmoss (Sun Gro Horticulture, Agawam, MA) in 50cell vacuum propagation sheets (Dillen-ITML, Middlefield, $\mathrm{OH}$ ) inserted into 1020 trays $(21.0 \times$ $10.75 \times 2.5$ inches $)$. All woody plant species were propagated in $3: 1(\mathrm{v} / \mathrm{v})$ perlite:peatmoss, and all herbaceous perennials were propagated in $1: 1$ $(\mathrm{v} / \mathrm{v})$ perlite:peatmoss. Each overhead mist system was built on a separate $3 \times$ 8 - $\mathrm{ft}$ greenhouse bench in a glassglazed greenhouse. An overhead mist system consisted of three floramist nozzles connected to $1 / 2$-inch polyvinyl chloride on risers. A separate battery-operated timer (Mist Timer II; Drips, Concho, AZ) for each overhead mist system turned on the mist for $10 \mathrm{~s}$ every $10 \mathrm{~min}$ from 6:30 $\mathrm{AM}$ until 7:30 PM.

The commercial-scale submist systems were modified versions of the submist used in previous experiments (Peterson et al., 2018a, 2018b;
Sanchez et al., 2020). In this version of the system, 6 - $\mathrm{ft} \times 3$ - $\mathrm{ft} \times 7$-inch ebband-flow tables (Active Aqua Premium High Rise Flood Table AAHR36W; HydroFarm, Petaluma, CA) were set on greenhouse benches as aeroponic rooting chambers (Fig. 1). Within each rooting chamber, we constructed a manifold of mist nozzles using $1 / 2$-inch tubing with six mist nozzles (T-Spray; Senninger, Clermont, FL) installed. A 1-horsepower lawn pump (Utilitech; Lowe's Home Improvement, Mooresville, $\mathrm{NC}$ ) with a 6-ft leader hose connected to a foot valve (Star Water Systems, Kendallville, IN) pulled the water from a sump basin (Jackel, Mishawaka, IN) and delivered it to the manifold. The pump was plugged to a timer (Titan Controls Apollo 12; Sunlight Supply, Vancouver, WA) that turned on the mist for $10 \mathrm{~s}$ every $10 \mathrm{~min}$. Excess water drained from the ebb-and-flow table, at which point it was returned to the sump basin. The submist chamber was covered using a piece of vinyl lattice with a $11 / 8$-inch grid size (Fig. 1A), over which was placed $5.5-\mathrm{mm}$ black-andwhite polyethylene film with the white side facing out (HydroFarm). The lid was attached to the ebb-andflow bench with 10 spring clamps. Before inserting a cutting, a hole was poked in the plastic film at the center of a lattice grid hole using the point of a pencil (Fig. 1B).

Environmental conditions and water use were monitored. A weather station (EM50; Meter Group, Pullman, WA) with a quantum light sensor (SQ120; Apogee Instruments, Logan, UT) and combined temperature and relative humidity sensor (VP-4, Meter Group) monitored the environment. The mean daily temperature was $25^{\circ} \mathrm{C}$, the daily light integral (DLI $=$ Mean photosynthetically active radiation $\times 0.0864$ ) was $17 \mathrm{~mol} \cdot \mathrm{m}^{-2} \cdot \mathrm{d}^{-1}$, and the relative humidity was $64 \%$ during the experiment. The quantity of water added to each replicate system was noted throughout the propagation period. For submist, this was observed manually. We noted the water added to sump basins at the beginning of the experiment and recorded how much water was added until the final rooted cuttings were harvested on 29 July. Flow meters ( $1 / 2$-inch, model DLJSJ50; Daniel L. Jerman Co., 

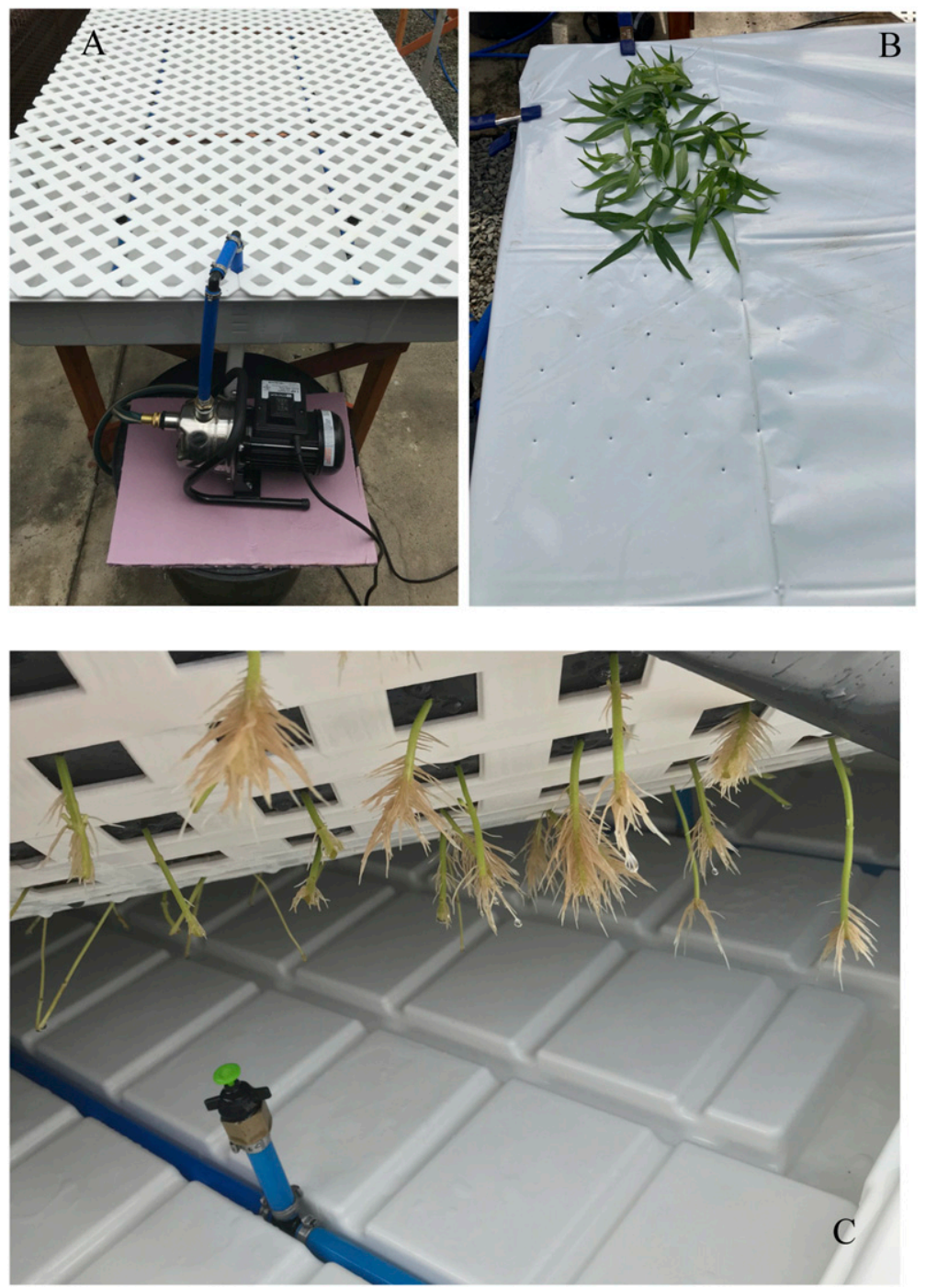

Fig. 1. A commercial-scale submist system was used in our study to propagate five nursery crops by stem cuttings. It consisted of $(A)$ an ebb-and-flow bench covered with lattice, as well as a reservoir and a pump connected to a manifold of nozzles. (B) The lattice was covered with plastic film that was black on the lower surface and white on the upper surface, and holes were created in the film to insert cuttings.

(C) Nozzles and formation of roots in the system are shown.

Hackensack, NJ) were installed inline to record the volume of water used by each overhead mist system during the entire study duration, ending on 29 July.

When cuttings in either system were rooted, all cuttings of that species were harvested (faassen nepeta, 2 and 3 July; blue star flower, 17 July; panicle hydrangea, 18 July; sweetgale, 19 July; sweetfern, 29 July) from both systems. Cuttings were considered well rooted when a majority of them had enough roots that they would survive transplanting (a root rating of 3 or greater using the scale described next). Data collected from cuttings included a subjective root rating, the length of the longest root, the number of roots, and root dry weight. For the root ratings (all plants except faassen nepeta), subjective ratings were assigned for root system quality on a scale from 0 to 5 , where 0 is no roots, 1 is one to several roots (not transplantable), 2 is a lopsided and/ or weakly developed root system, 3 is a moderately developed root system, 4 is a well-developed root system, and 5 is an extensive root system distributed symmetrically around each cutting. Root dry weight was recorded for each cutting after roots were washed and bagged, and roots were dried in a room heated to $68{ }^{\circ} \mathrm{C}$ for a minimum of 1 week. Faassen nepeta was rated on a scale from 1 to 5 , where $l$ is a cutting that had no roots, 2 is a cutting with a modest number of roots, 3 is a cutting with an intermediate root system and likely to survive transplanting, 4 is a cutting that is fairly well developed, and 5 is an extensive and symmetrical root system.

The experiment was conducted as a randomized complete block design, with three blocks for each experimental unit. We began the experiment with five blocks, but two of the submist systems were compromised by mechanical failures early during the propagation period. Nozzles in one of the submist systems became clogged by debris in the line, and the pump in another submist system failed to hold its prime. Therefore, cuttings were harvested from only three blocks for data analysis. Within blocks, an experimental unit consisted of a bench-scale submist system or an overhead mist system. Each species in the system was analyzed as a separate experiment, with individual cuttings serving as subsamples. There were 21 subsamples for faassen nepeta and 10 subsamples for all other species. Data from subsamples in each block were averaged before analysis using JMP Pro 14 (SAS Institute, Cary, NC) and analysis of variance.

\section{Results and discussion}

The commercial submist system performed as well as the alternative propagation system for the five species we studied (Fig. 1C). Compared with overhead mist, rooting in submist was comparable [sweetfern, sweetgale, and panicle hydrangea (Table 1)] or superior [blue star flower, faassen nepeta (Tablel)]. These findings are consistent with previous studies using submist, in which manchurian lilac, inkberry (Ilex glabra), and coleus produced more roots and longer roots in submist than in overhead mist (Peterson et al., 2018a, 2018b; Sanchez et al., 2020).

Root number and quality rating of the two herbaceous perennials in the study-blue star flower and faassen nepeta-were both significantly greater when they were propagated using submist systems (Table 1). When cuttings were propagated in submist, root ratings were $84 \%$ and $34 \%$ greater for blue star flower and 
Table 1. Root rating, root length, root number, and root dry weight of cuttings of five plant species propagated in submist and overhead mist systems. Means for each system are presented for each species; $n=3$, with each replicate the average of 21 subsamples (faassen nepeta) or 10 subsamples (all other species). The experiment was conducted from 20 June to 29 July 2019 in Orono, ME.

\begin{tabular}{|c|c|c|c|c|c|}
\hline Species & System & $\begin{array}{l}\text { Root rating } \\
(0-5 \text { scale })^{\mathrm{z}}\end{array}$ & $\begin{array}{c}\text { Root } \\
\text { length }(\mathrm{cm})^{\mathrm{y}}\end{array}$ & $\begin{array}{l}\text { No. of } \\
\text { roots }\end{array}$ & $\begin{array}{l}\text { Root dry } \\
\text { wt }(\mathrm{mg})^{\mathrm{y}}\end{array}$ \\
\hline \multirow[t]{3}{*}{ Blue star flower } & Submist & 3.13 & 9.86 & 70.9 & 56.1 \\
\hline & Overhead mist & 0.5 & 0.34 & 18.2 & 3.68 \\
\hline & $P$ value & $0.0007^{x}$ & 0.0465 & 0.0095 & 0.0461 \\
\hline \multirow[t]{3}{*}{ Faassen nepeta } & Submist & 2.69 & 4.24 & 59.9 & 25.1 \\
\hline & Overhead mist & 1.78 & 0.32 & 9.68 & 1.05 \\
\hline & $P$ value & 0.0097 & 0.0008 & 0.0108 & 0.0019 \\
\hline \multirow{3}{*}{ Sweetfern } & Submist & 1.77 & 3.78 & 18.3 & 9.48 \\
\hline & Overhead mist & 1.1 & 4.56 & 6.73 & 15.1 \\
\hline & $P$ value & NS & NS & NS & NS \\
\hline \multirow[t]{3}{*}{ Sweetgale } & Submist & 3.03 & 5.06 & 15 & 23.7 \\
\hline & Overhead mist & 2.83 & 5.19 & 12.6 & 41.2 \\
\hline & $P$ value & NS & NS & NS & NS \\
\hline \multirow{3}{*}{ Panicle hydrangea } & Submist & 3.1 & 2.92 & 138 & 26.3 \\
\hline & Overhead mist & 2.9 & 3.65 & 94.3 & 39.5 \\
\hline & $P$ value & NS & 0.0345 & 0.0062 & NS \\
\hline
\end{tabular}

${ }^{{ }^{Z}}$ Roots of blue star flower, sweetfern, sweetgale, and panicle hydrangea were rated on a scale from 0 to 5 , where $0=$ no roots, $1=$ one to several roots $($ not transplantable), $2=$ a lopsided and/or weakly developed root system, $3=$ a moderately developed root system, $4=$ a well-developed root system, and $5=$ an extensive root system distributed symmetrically around each cutting. Roots of faassen nepeta were rated on a scale from 1 to 5 , where $1=$ no roots, $2=$ a modest number of roots, $3=$ an intermediate root system likely to survive transplanting, $4=$ a fairly well-developed root system, and $5=$ an extensive and symmetrical root system.

${ }^{\mathrm{y}} 1 \mathrm{~cm}=0.3937$ inch, $1 \mathrm{mg}=3.5274 \times 10^{-5} \mathrm{oz}$

${ }^{\mathrm{x}}$ Data from subsamples in each block were averaged before analysis of variance. Probability values are shown for treatment effects that are significant at $\alpha=0.05$; NS $=$ not significant.

faassen nepeta, respectively (Table 1). Similarly, root length increased by 97\% and $92 \%$ for blue star flower and faassen nepeta, respectively ( $\mathrm{Ta}-$ ble 1), when they were propagated in submist. Cuttings of herbaceous perennials developed a mean of 50 additional roots in submist compared with overhead mist, where neither species grew more than 20 roots on average (Table 1). Root dry weight of blue star flower and faassen nepeta was $93 \%$ and $96 \%$ greater, respectively, in submist (Table 1).

'Walker's Low' faassen nepeta typically roots in 3 to 4 weeks in overhead mist; however, plants are slower to root when they are flowering (Pilon, 2007). Our cuttings were flowering when collected, and they rooted in 12 to $13 \mathrm{~d}$ in the submist system. Cuttings in overhead mist systems may have produced a comparable number of roots given more time. Blue star flower propagated in submist rooted in $27 \mathrm{~d}$. Blue star flower roots relatively reliably when it is propagated from stem cuttings (Cullina, 2000). We worked with this plant because growers in the northeastern United States find it to be slow to root (Van Berkum Nurseries, unpublished data). Although $27 \mathrm{~d}$ is not a quick propagation time for an herbaceous perennial, it is likely that the plants propagated in submist had more roots because the roots formed more quickly compared with overhead mist. These are the first herbaceous perennials we have propagated in submist. However, the results we observed agree with those reported for the annual plant coleus (Peterson et al., 2018b). Cuttings of coleus propagated in submist had more and longer roots, and the dry weight of root systems was greater than those of coleus propagated in overhead mist (Peterson et al., 2018b).

Panicle hydrangea had a greater root number (mean, 44) when propagated in submist (Table 1 ). However, there was no difference in root rating or dry weight, and root length was greater when panicle hydrangea was propagated in overhead mist [20\% longer (Table 1)]. Panicle hydrangea formed roots in $28 \mathrm{~d}$. Compared with some of the other species propagated in this study, panicle hydrangea (and other hydrangea species) is considered easy to root (Hartmann et al., 2002). In previous studies, two other woody plant species, manchurian lilac and inkberry, produced more and longer roots in submist than in overhead mist (Peterson et al., 2018b; Sanchez et al., 2020).
There were no significant differences in rooting measures for either sweetfern or sweetgale grown in both propagation systems (Table 1 ). It seems that rooting response to submist and overhead mist varies from one species to another. We are unsure why submist may provide a superior environment for some plants and not for others. However, there has been scant research exploring the impact of the propagation environment on root formation. Twinflower (Linnaea borealis) roots best in an environment with relatively low light $(\mathrm{DLI}=5.8-$ $\left.14.4 \mathrm{~mol} \cdot \mathrm{m}^{-2} \cdot \mathrm{d}^{-1}\right)$ and high substrate moisture content $(0.30-0.35 \theta)$, conditions that are qualitatively similar to natural environments for this plant (Foster et al., 2017). In our study, it is possible that the rooting environment is more appropriate for some plants because it mimics their natural environment. In a previous study, the vapor pressure deficit and temperatures at canopy height and in the rooting zone were greater for submist than for overhead mist (Sanchez et al., 2020). It is also possible that higher temperatures in submist encourage root growth in some species. Root-zone temperature can increase rooting of red fountain grass (Pennisetum $\times$ advena), particularly when 
DLI is low (Owen and Lopez, 2018). However, sweetfern roots at greater percentages in the cooler environment provided by overhead mist than in the warmer environment of a propagation dome (Griffith Gardner et al., 2019). Controlled studies are necessary to identify the environmental contributions to root formation for different species in different systems.

Water usage was significantly lower in the submist systems, which used 98\% less water than the overhead mist systems (Table 2 ). Submist systems used an average of $55 \mathrm{~L}$ of water, including the water remaining in the system at the end of the study, whereas overhead mist systems used an average of $2403 \mathrm{~L}$. We estimate this would be equivalent to $3 \mathrm{~L} / \mathrm{ft}^{2}$ of water applied for submist and $100 \mathrm{~L} /$ $\mathrm{ft}^{2}$ applied in overhead mist. The submist propagation system recirculates water, which is one reason for this reduction. Little water is lost to evaporation compared with overhead mist. Even for plants with equivalent rooting in submist compared with overhead mist, a reduction in water usage could be considered an advantage. Substantial research has focused on finding techniques for reducing water use during plant production (van Iersel et al., 2013). There has been little focus on reducing water during propagation. Previous work has focused on dynamic, rather than static, control of overhead mist systems (Wilkerson et al., 2005; Zolnier

Table 2. Water used for submist and overhead mist systems during propagation of five nursery crops by stem cuttings from 20 June to 29 July 2019. This experiment was conducted in Orono, ME. The systems differed in water use $(P=0.0001)$.

\begin{tabular}{lcc}
\hline System & Block & Water use $(\mathrm{L})^{\mathrm{x}}$ \\
\hline Submist & 1 & $58^{\mathrm{y}}$ \\
& 2 & 60 \\
& 3 & 48 \\
Overhead mist & Average & 55 \\
& 1 & $2,298^{\mathrm{x}}$ \\
& 2 & 2,423 \\
& 3 & 2,487 \\
& Average & 2,403 \\
\hline
\end{tabular}

${ }^{\mathrm{z}} \mathrm{l} \mathrm{L}=0.2642 \mathrm{gal}$

${ }^{\mathrm{y}}$ The volume of water added to each submist system was measured manually over the study duration.

${ }^{\mathrm{x}}$ The volume of water used by each overhead mist system was measured by a water flow meter installed inline. et al., 2003). These systems, which initiate mist based on evapotranspiration, can reduce water usage by $55 \%$ (Wilkerson et al., 2005). Submist provides another option for reducing water use while producing cuttings with equivalent or superior root systems. It is likely that reducing water in submist will impact production costs, such as water and electricity to run pumps. However, calculating these costs was beyond the scope of our research and would be difficult to predict, particularly given differences in water costs regionally and whether water is coming from a well or a municipal source (Raudales et al., 2017).

Previous work using submist was conducted in small, research-scale systems (Peterson et al., 2018a, 2018b; Sanchez et al., 2020). In contrast, the system in our study was built to be operated on a commercial scale. Currently, most parts of the system, including ebb-and-flow tables, pumps, sump basins, mist nozzles, and miscellaneous plumbing supplies, are available to growers commercially. The greatest challenge was creating the lid of the system, which was custom-built and not available in one piece on the market. Although the lattice and plastic film succeeded in holding cuttings in place, we would like to build a lid that is easier to use and has a watertight fit. The lattice allowed cuttings to be spaced at a density similar to that of 50 -cell propagation trays, but inserting and removing the cuttings from this lid required care. Our commercially scaled-up submist system cost about $\$ 630$ in parts to construct each $6 \times 3$ - $\mathrm{ft}$ unit $\left(\$ 35 / \mathrm{ft}^{2}\right)$. Of this cost, more than half was accounted for by the flood table $\left(\$ 11 / \mathrm{ft}^{2}\right)$ and pump $\left(\$ 9 / \mathrm{ft}^{2}\right)$. For comparison, each $8 \times 3$ $\mathrm{ft}$ mist bench cost about $\$ 270$, or $\$ 11 / \mathrm{ft}^{2}$. However, both systems could be scaled differently, altering the cost per square foot. For overhead mist, we used a different mist timer for each bench, but growers use a single timer for a much larger propagation space. For submist, using larger ebb-and-flow tables, tables of a lower grade, and/or more tables fed by a single pump, would reduce the cost per unit area considerably. The ebband-flow bench used as the submist rooting chamber could also be used for production as well as propagation, which might provide more flexibility and make the cost more acceptable. It was relatively easy to propagate cuttings that needed to be rooted at different times during the season in this system and to remove them when they formed roots, which were accessed readily by lifting the lid.

\section{Conclusions}

Faassen nepeta and blue star flower had superior overall rooting in submist compared with overhead mist. Panicle hydrangea propagated in submist had more, but shorter, roots than those in overhead mist. Sweetfern and sweetgale were comparable when propagated in both systems. It appears that some plants may have superior, or quicker, rooting in submist. This system may provide advantages to growers who are propagating difficult-to-root plants. In addition, submist used a fraction of the water used by overhead mist. Some growers may find the water savings in propagation a benefit to using this system.

\section{Literature cited}

Coston, D.W., G.W. Krewer, R.C. Owings, and E.G. Denny. 1983. Air rooting of peach semihardwood cuttings. HortScience 18:323-324.

Cullina, W. 2000. Wildflowers: A guide to growing and propagating native flowers of North America. Houghton Mifflin, Boston, MA.

Foster, J., S. Burnett, and L. Stack. 2017. Effects of light, soil moisture, and plant nutrition on greenhouse propagation of twinflower. HortTechnology 27:782-788, doi: 10.21273/HORTTECH03685-17.

Griffith Gardner, J.A., J.D. Lubell, and M.H. Brand. 2019. Propagation of Comptonia peregrina L. from stem cuttings. HortScience 54:511-513, doi: 10.21273/HORTSCI13770-18.

Hartmann, H.T., D.E. Kester, F.T. Davies, Jr., and R.L. Geneve. 2002. Hartmann and Kester's plant propagation: Principles and practices. 7th ed. Pearson, Upper Saddle River, NJ.

Nitsch, J.P. 1964. Propagation in the year 2000. Intl. Plant Prop. Soc. Proc. 14:316-324.

Owen, W.G. and R.G. Lopez. 2018 Propagation daily light integral and rootzone temperature influence rooting of single-internode Pennisetum $\times$ advena culm cuttings. HortScience 53:176-182, doi: 10.21273/HORTSCI12455-17. 
Peterson, B.J., S.E. Burnett, and O. Sanchez. 2018a. Submist is effective for propagation of korean lilac and inkberry by stem cuttings. HortTechnology 28:378-381, doi: 10.21273/HORTTECH03970-18.

Peterson, B.J., G.J.R. Melcher, A.K. Scott, R.A. Tkacs, and A.J. Chase. 2019. Propagation of sweetgale, rhodora, and catberry by stem cuttings. HortTechnology 30:38-46, doi: 10.21273/HORTTECH04464-19.

Peterson, B.J., O. Sanchez, S.E. Burnett, and D.J. Hayes. 2018b. Comparison of four systems for propagation of coleus by stem cuttings. HortTechnology 28:143-148, doi: 10.21273/HORTTECH03926-17.

Pilon, P. 2007. Nepeta $\times$ faasseni 'Walker's Low'. 6 Aug. 2020. <https://gpnmag. com/article/inepeta- $x$-faasseniii-walkerslow $/>$.

Raudales, R.E., P.R. Fisher, and C.R. Hall. 2017. The cost of irrigation sources and water treatment in greenhouse production. Irr. Sci. 35:43-54, doi 10.1007/s00271-016-0517-5.

Sanchez, O., S.E. Burnett, and B.J. Peterson. 2020. Environment, photosynthesis, and adventitious rooting of manchurian lilac cuttings propagated in overhead mist, submist, and combination systems. HortScience 55:78-82, doi: 10.21273/HORTSCI14473-19.

Santos, K.M., P.R. Fisher, and W.R Argo. 2008. A survey of water and fertilizer management during cutting propagation. HortTechnology 18:597-604, doi: 10.21273/HORTTECH.18.4.597. van Iersel, M.W., M. Chappell, and J.D. Lea-Cox. 2013. Sensors for improved efficiency of irrigation in greenhouse and nursery production. HortTechnology 23:735-746, doi: 10.21273/HORTTECH.23.6.734

Wilkerson, E.G., R.S. Gates, S. Zolnier, S.T. Kester, and R.L. Geneve. 2005. Transpiration capacity in poinsettia cuttings at different rooting stages and the development of a cutting coefficient for scheduling mist. J. Amer. Soc. Hort. Sci. 130:295-301, doi: 10.21273/JASHS. 130.3.294

Zolnier, S., R.S. Gates, R.L. Geneve, and J.W. Buxton. 2003. Evapotranspirationbased misting control for poinsettia propagation. Trans. Amer. Soc. Agr. Eng. 46:135-145. 